\title{
FAULT DETERMINATION DUE TO SINKHOLE ARRAY ON LAR VALLEY, NORTHEAST OF TEHRAN (IRAN)
}

\author{
DOLOČANJE PRELOMOV NA PODLAGI RAZPOREDITVE \\ POŽIRALNIKOV V DOLINI LAR, SEVEROVZHODNO OD \\ TEHERANA (IRAN)
}

\author{
Ahmad KHORSANDI ${ }^{1}$, Takao MIYATA ${ }^{2}$
}

\begin{abstract}
UDC 551.243.1(551)

Ahmad Khorsandi \& Takao Miyata: Fault determination due to sinkhole array on Lar valley, northeast of Tehran (Iran)

The main objective of this paper is to present an approach to identify active faults in karstic enviroments. This is achieved by a releasing relationship between sinkholes or dolines formation, array and active faults mechanism. In this research, Lar valley on the Northeast of Tehran, Capital of Iran was selected as a case study. The sinkholes array in the valley shows that their formation and location is influenced by active faults. As a result of active faults mechanism, a number of young and old dolines have been formed on north and south of the study area. According to Aerial Photographs, Satellite images and geological logs corelation three major active faults were distingushed in the study area specially under Lar dam structure. Two of the faults are elongated to the north and the one extends to the south, seven sinkholes were formed on faults. Based on the available evidences, it is assumed that the formation and array of dolines in the study area has been formed and controlled by active faults. Conversely, it is deduced that faults activity may be determinated by sinkholes formation and array. This results may be applied for the similar cases of world,s karstic belt.

Key words: sinkhole array and formation, active fault determination, Lar valley, Iran.
\end{abstract}

Izvleček

UDK 551.243.1(551)

Ahmad Khorsandi \& Takao Miyata: Določanje prelomov na podlagi razporeditve požiralnikov $v$ dolini Lar, severovzhodno od Teherana (Iran)

Članek poskuša predstaviti pristope k ugotavljanju aktivnih prelomov na krasu. Metoda temelji na ugotavljanju razmerij med nastajanjem in porazdelitvijo požiralnikov (oziroma vrtač), ter na aktivnem tektonskem mehanizmu. Obravnavano je območje doline Lar, severovzhodno od Teherana. Razporeditev požiralnikov vzdolž doline nakazuje, da je nastanek oziroma lokacija požiralnikov povezana $\mathrm{z}$ aktivnimi tektonskimi premiki ob prelomih. Na severni in južni strani doline je nastalo večje število relativno mlajših oziroma starejših vrtač. $S$ pomočjo satelitskih posnetkov in korelacij so določili tri večje aktivne prelome na obravnavanem območju, posebej blizu jezu Lar. Ob prelomih, od katerih dva vpadata proti severu in eden proti jugu, je nastalo sedem požiralnikov. V skladu z razpoložljivimi podatki sklepajo, da je nastanek in razporeditev požiralnikov posledica aktivnih tektonskih premikov ob prelomih. Sklepamo lahko tudi obratno, torej da so aktivni premiki ob prelomih povezani z nastankom in razporeditvijo požiralnikov. Rezultati raziskave bi bili lahko uporabni v številnih podobnih primerih, ki se pojavljajo na kraškem terenu širom po svetu.

Ključne besede: nastanek in razporeditev požiralnikov, aktivna seizmika ob prelomih, dolina Lar, Iran.

\section{INTRODUCTION}

To understand the dolines formatin which is affected by active faults mechanism, it is neccessary to identify active faults on the basis of array formation of the Sinkholes.
In order to protect the areas with sinkhole formation we need to consider following cases:

\footnotetext{
${ }^{1}$ Power and Water Institute of Technology, Shahid Abaspor Street, Tehranpars, Tehran, Iran; e- mail: Khorsandi@pwit.ac.ir Tel. 9821 7310044, P o. Box 16765-1719.

2 Dept. of Earth and Planetary Scinces, Kobe University, Kobe, Japan; e-mail:miyata@kobe-u.ac.jp7.

Received/Prejeto: .16.03.2006
} 
1-Urban area

2-Farmland

3-Irrigation systems

4-Pump station

5- Electrical power generation

6-Water well muding

7-Collaps of different structure and buildings

8- Induced earthquakes

9- Unstable earth around sinkholes

There are a number of case studies that present strong evidences of the above mentioned list.. Milanovic(1981) discussed of tectonic influence on dolines formation proccess, Rezai and Zamanian in 1988 demonstrated sinkholes array (260 sinkholes) that is formed by thrust fault. However, the influence of active faults is observed on karstification and hydrogeology regime in west of sweden (Herold et al.,1988). Sustersic (2003) states which water collector of Dollines is controled by active faults crushed zone. A number of researches have stated active faults and tectonic affects on karstification and groundwater (Fazeli, 1988; Kenz, 1988; Edgell, 1993; Celik and Onsal, 1999; Maloszweki et al., 1999; Kusamayudha et al., 2000; Taylor and Howard, 2000; Fernandes and Rudolph, 2001; Clarke, 2003). Haydari et al 2003, Amiri 2003 , Sadati and Mohamadi 2003, observed for- mation of many sinkholes (39) with different sizes on faults direction, in Hamadan plain, in northwest of Iran. The formation of sinkholes has led to many problems for farmland, irrigation systems, water wells and power electric generation. dolines formation may also occure gradualley or suddenly in urban area, this was observed in 1981 winter park sinkhole in Florida, which destroyed a large part of a city block, sent shock waves throughout the popular media (Edlane 1993). The objective of this paper is to demonstrate relationship between Lar valley sinkholes array and active faults .since occurrence of sinkholes affected by active faults mechanism in urban area and plains causes a great deal of problems, it is important to study dolines in order to protect urban area and plain so that reduce cost of damages. In other hand ,on basis of above experiences, determination of active faults and their locations is possible that is important in seismology so that the information apply for buildings ,urban area and other structures damage protection.

The case study of Lar valley sinkholes resulted in identification of active faults and their effect on formation of dolines. The results of this survey shows that ,it is possible to estimate active faults and their location on basis of sinkholes situation along faults direction in world which their condition are similar

\section{LAR VALLEY SINKHOLES AND ACTIVE FAULTS CHARACTERESTIC}

Lar region is located at northeast of Tehran city, Iran with $\mathrm{E} 51^{\circ}, 35^{\prime}$ to $\mathrm{E} 52^{\circ}, 00$ ', longitude and ; $\mathrm{N} 35^{\circ}, 51^{\prime}$ to $\mathrm{N} 36^{\circ}, 5^{\prime}$ latitude(Fig 1a). It is a large valley with an area of 724 $\mathrm{km} 2$, which is in Alborz mountains,part of Alp- Himalyaan orogenic belt, that is located on world karstic belt. Mount Damavand with elevation of $5670 \mathrm{~m}$ and Lar river in the east part with elevation of $2460 \mathrm{~m}$ are respectively highest and lowest points of Lar valley.

Lar reservior dam which has been constructed in the east of study area has leakage since refilling the reservior and few young dolines have been formed in lake deposites behind the dam (Asadi 1995).

Stratigraphic sequence of the study area is as follows:

Mezozoic: The Mezozoic in the study area is contained of Jurassic system which is the limestone (Lar limestone). It is a thin-bedded to massive which contains many karstic phenomena and is fractured by tectonic. The Lar formation is located in right and left bank of the Lar dam. (Figs 4 and 6).

Cenozoic: The Cenozoic includs Quaternary lava and alluvium. The lava is outcroped in the middel and left banks of the Lar dam (Figs 4,6). It is contained Tra- chy andesite and Trachyte. The Alluvium is young,old and lake deposit (Figs 2,4 ,6) (Shahrabi and Sidi, 1984; Giahi, 1989). The age of alluviall is Holocene that deposited about 38500 years ago (late Plestocene) (Allenbach, 1966).

\section{SINKHOLES OF THE LAR VALLEY}

Nine sinkholes are developed in the sediments, which filled the Lar dam Lake banks (Figs 1b, 2,4,5,6). The array of the sinkholes is in the direction of E-W. Four of them are young, with a sharp outline (Figs 2,4,5), appeared during 1980-1989. Their diameters vary between 5-40 m and depths of 5-22 m. The ratio of diameter to depth was computed in the rang of 0.6 to 4 (Table 1 ).

The ancient sinkholes are Five having collapsed walls, which can be found on course-grain alluvial (Figs $2,4,5)$. It is noted that the depth is considered by low, thus is due to the fact that collapsed wall sedimentation is deposited into hole (Table 1). The ancient sinkholes diameter is 5 to $80 \mathrm{~m}$ and their depth vary between 4 to 5 $\mathrm{m}$, except S8 and S9 in Table 1. 

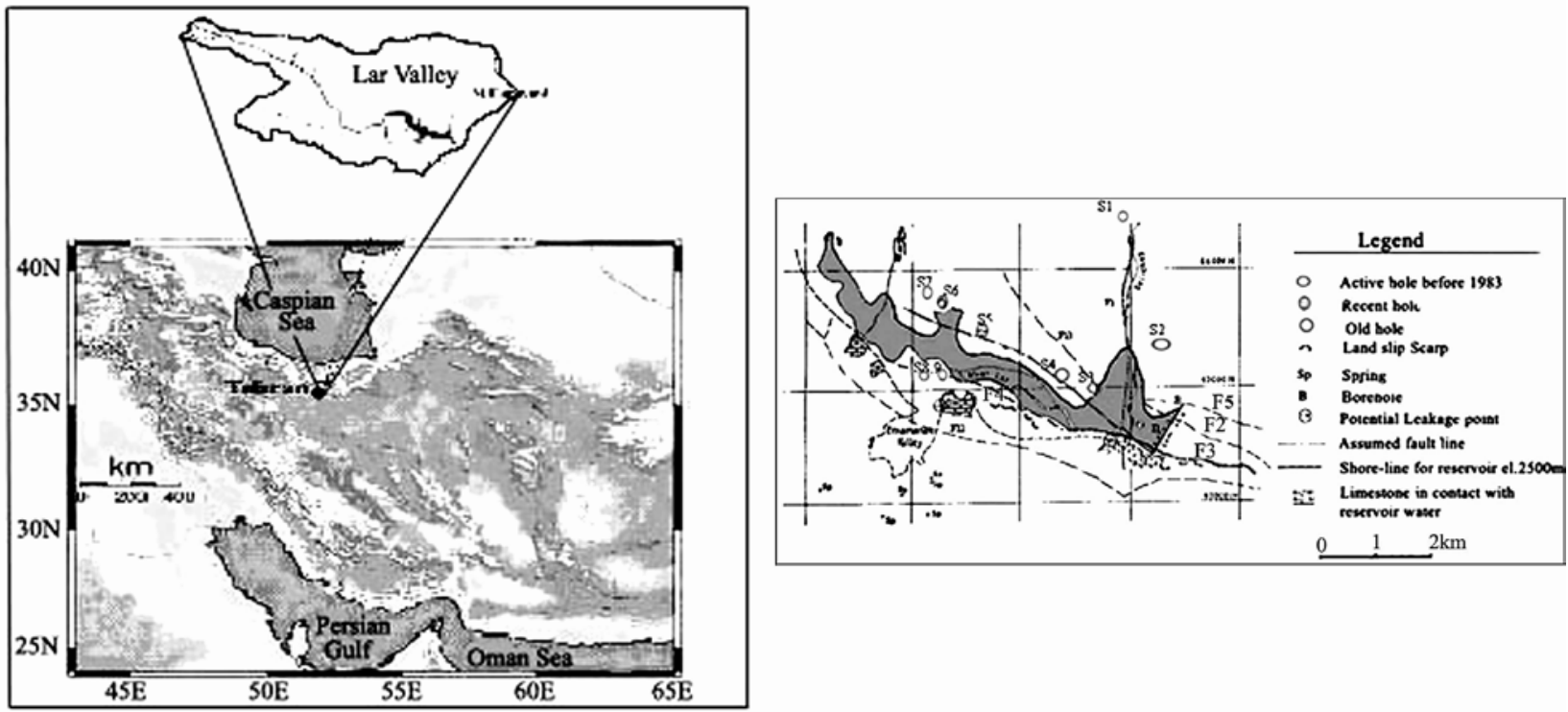

Fig.1: a) Location of the Lar dam region, northeast of Tehran. b) Location of the Lar dam and distribution of sinkholes and active faults.

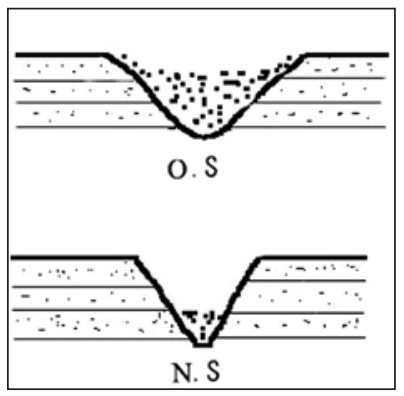

Fig. 2: Cross section of young (N.S) and ancient sinkholes (O.S) that shows erossion filling and collapse.

of airphotograph, satellite images, excavation data and boreholes geological logs corelations.

Lar valley airphotograph and Satellite images study delineate F1 and F2 faults (Fig 1b).

Geotechnical and Engineering Geology surveys of gallery and boreholes in the Lar limestone distingushed many faults and karst phenomena (i.e cave, gallery,....) (Tehran Water Org., 1976; Giahi, 1989). The study of Lar formation (Jurassic) excavations shows that it has a thickness from the surface to $140 \mathrm{~m}$ below, and there after karaj formation (Eocene) is observed, which are good evidences to prove the existance of F4 thrust fault in lar valley (Fig 1b and 6 ). A big cave was also observed in 105-106 m deep. In borehole from one of the galleries, 13 caves were observed in $240 \mathrm{~m}$ depth,which is a good evidence on the existance of the fault and its influence on karstification. In boreholes from two galleries, erosion and crushing are evident which prove existance of fault.

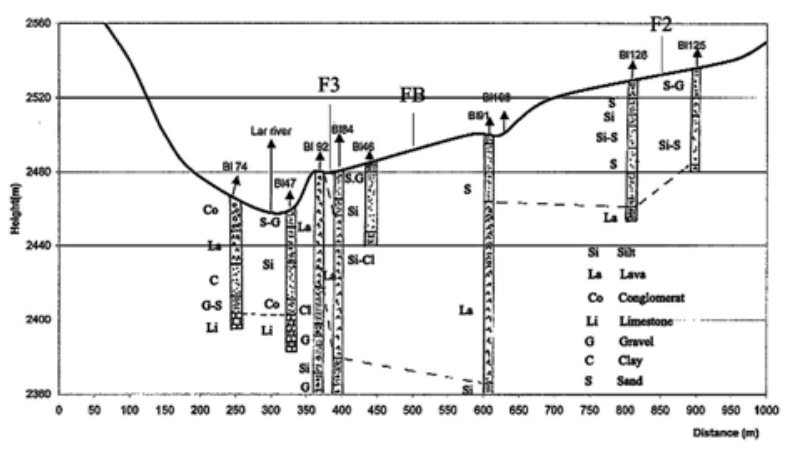

Fig. 3: Geological log of boreholes in direct to dam axis in Fig.1b, With the important F3, FB faults and F2 fault that distingushed by displacement Formatio in boreholes.

In this research many boreholes were selected along the Lar dam axis. (Fig 3) Correlation of boreholes geological $\log$ has distingushed three active faults and their mechanism (F2, F3 and FB in Fig 3).

Three types of faults are mainly determined in the study area and their around, normal, reverse and thrust faults.

Normal faults are principally elongated in three directions namely NW-SE, NE-SW and N-S, they are located in the south and northeast of the valley. Reverse faults have NW-SE direction and dip strike toward NE. These are located at southwest of the Lar valley. Thrust faults are directed NW-SE with dip strike toward NE which are located in the south of valley. Further information about faults were also obtained from the study area that are discussed here. 


\begin{tabular}{|l|l|l|l|l|l|l|l|}
\hline No & Symbol & $\begin{array}{l}\text { Geographical } \\
\text { Cox }\end{array}$ & $\begin{array}{l}\text { Geological } \\
\text { Formation }\end{array}$ & Location & $\begin{array}{l}\text { Diameter- } \\
\text { Depth }\end{array}$ & $\begin{array}{l}\text { Date of } \\
\text { formation }\end{array}$ & Fault \\
\hline 1 & S1 & $51,59.5-35,55.5$ & Lake Deosit & $\begin{array}{l}\text { Lar, Dalichai } \\
\text { across }\end{array}$ & -------- & Ancient & Dalichai fault \\
\hline 2 & S2 & $51,59.5-35,54.7$ & Lake Deosit & // // & $\begin{array}{l}\text { Dia. }=10 \mathrm{~m} \\
\text { Depth=5 m }\end{array}$ & 1980 & $\begin{array}{l}\text { Dalichai, F3 } \\
\text { fault }\end{array}$ \\
\hline 3 & S3 & $52,58.7-35,54$ & $\begin{array}{l}\text { Alluvial, } \\
\text { lake Deposit }\end{array}$ & Nw of Dam & $\begin{array}{l}\text { Dia. }=5 \mathrm{~m} \\
\text { Depth=22 m }\end{array}$ & Ancient & F3 fault \\
\hline 4 & S4 & $51,58.7-35,54$ & $\begin{array}{l}\text { Alluvial, } \\
\text { lake Deposit }\end{array}$ & Nw of Dam & $\begin{array}{l}\text { Dia. }=13 \mathrm{~m} \\
\text { Depth=23 m }\end{array}$ & 1988 & F3 fault \\
\hline 5 & S5 & $51,57.7-35,54.5$ & $\begin{array}{l}\text { Alluvial, } \\
\text { lake Deposit }\end{array}$ & Nw of Dam & $\begin{array}{l}\text { Dia=5 m } \\
\text { Depth=18 m }\end{array}$ & 1988 & F3 fault \\
\hline 6 & S6 & $51,57-35,54.9$ & $\begin{array}{l}\text { Alluvial, } \\
\text { lake Deposit }\end{array}$ & Nw of Dam & $\begin{array}{l}\text { Dia.=80 m } \\
\text { Depth=4 m }\end{array}$ & Ancient & F3 fault \\
\hline 7 & S7 & $51,57.1-35,54.8$ & $\begin{array}{l}\text { Alluvial, } \\
\text { lake Deposit }\end{array}$ & Nw of Dam & $\begin{array}{l}\text { Dia. }=40 \mathrm{~m} \\
\text { Depth=10 m }\end{array}$ & 1989 & F3 fault \\
\hline 8,9 & S8, S9 & $51,57-35,53.5$ & Alluvial & Sw of Dam & $\begin{array}{l}--------- \\
\text { Ancient }\end{array}$ & F4 fault \\
\hline
\end{tabular}

Tab.1: Characters of existing sinkholes of Lra valley.

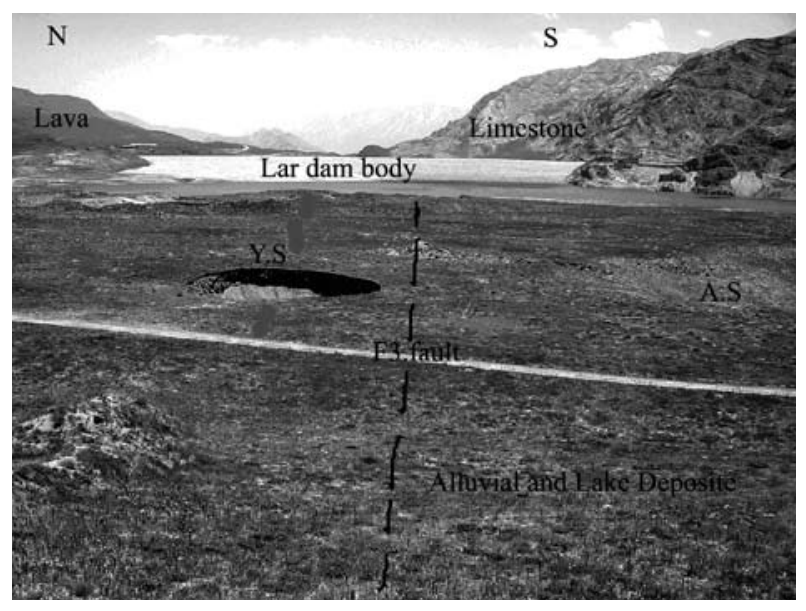

Fig. 4: Photo of sinkholes around Lar dam. AS is ancient sinkhole and YS is young sinkhole that assumed, their array influenced by the F3 fault.

FB fault is located between the B1 84 and B1 91 boreholes (Fig. 3) which displaced the lava about $40 \mathrm{~m}$ high. It is normal and active fault. F1 fault is located between B1 125 and B1 126 borehole (Fig. 3), it displaces natural drainage system and changes the geologic features of lava (i.e. color, composition and thickness of the lava). It is strike-slip and active fault which has $11 \mathrm{~km}$ long. The width of crushed zone is $50-10 \mathrm{~cm}$ and two ancient sinkholes were formed along that $\mathrm{F} 3$ fault is normal with $8 \mathrm{~km}$ long, which passes under Lar dam foundation, it displaces Lava $20 \mathrm{~m}$ high (Fig. 3). This is active and three young sinkholes were formed along that (Figs. 1b, 4 and 6).

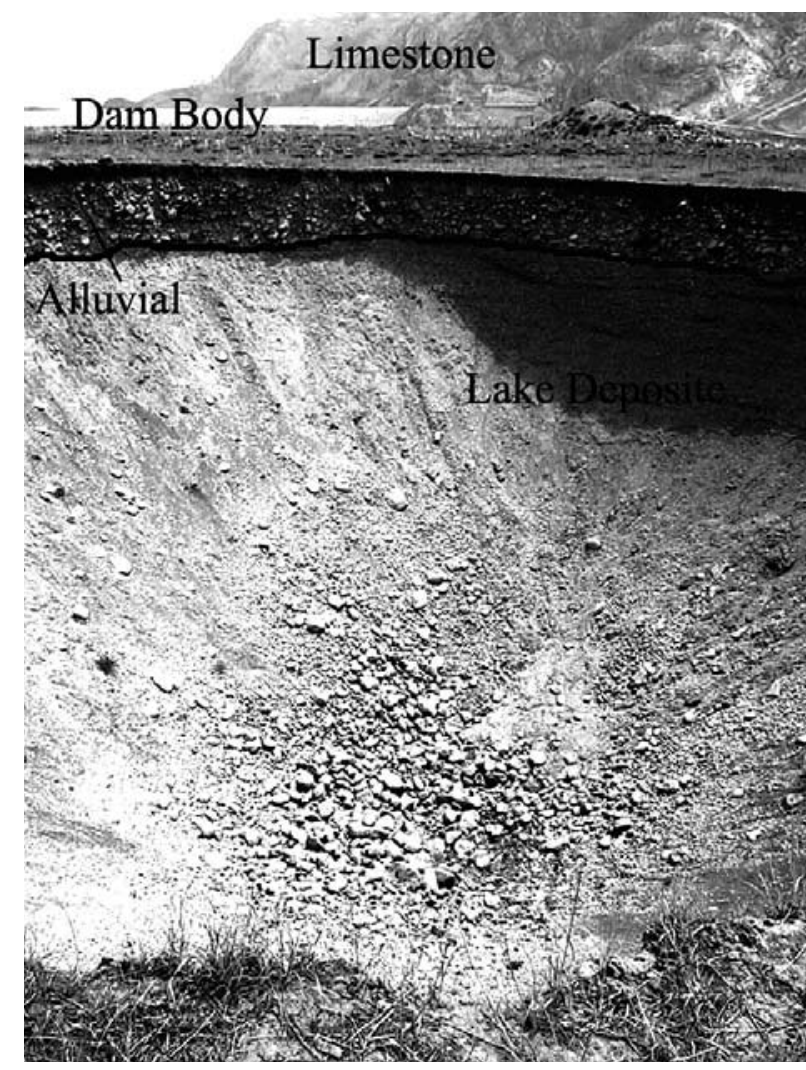

Fig. 5: Photo of young sinkhole containing lake deposit and alluvial.

The F4 fault is located in south of Lar valley, two old sinkholes are located along that (Figs. 1b and 6). It is 


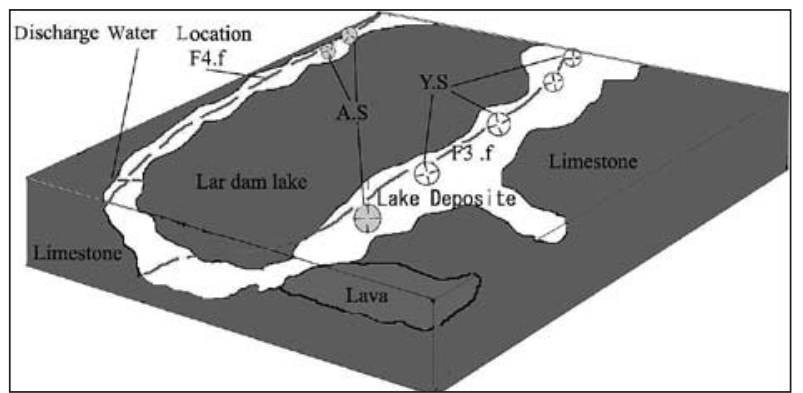

Fig. 6: Schematic diagrams illustrating the relationship between sinkholes and the F3 fault. Jurassic limestone; Lava is the Andesite and Trachyandesite. a thrust fault sloping towards south with crushed zone width approximatly $30 \mathrm{~cm}$. The crushed zone may be suggested to operate as an unerground channel to carry uncontrolled water discharge (Giahi 1989) of Lar Dam reservior further downstream (Fig 6).

Many evidences of structural geology imply that the mechanisms of F3 and F4 fault in the southern and F1 fault in the northern sides of the valley are responsible for new graben formation.

\section{DISCUSSION}

Finding and determining the active faults is an important topic in earth sciences. It is possible to determin them in karstic environment due to dolines array along faults in recent alluvial,where the fault is covered by alluvial.

The conclusion of research in Lar valley, distinguished that some old and young Sinkholes are formed by faults mechanisms in recent alluvial and lakes sediments. Since dolines are formed in the direction of faults, this, in turns may be strong evidence of faults Activity (USBR 1978). Active and capable faults of the study area are F1, F2, F3, F4 and FB. These faults were characterized by study of aerial phothographs, satellite images, and excavation data and geological log correlation.Fourthermore, several karstic phenomenas i.e caves, cavities and galleries have been formed in Lar limestone depths where they are superimposed on crushed zone and faults direction. Thus, the most appropriate guideline for primary identification of active faults in karstic enviroments is the pres- ence of sinkholes array there are other methods to indentify active faults underground.These methodes are geoelectric, geoseismic, GPR, trench, borehole excavation, well logging and groundwater surface anomally study. However here are some problems with applying these methods for active faults finding.Griffiths(1986) stated that geoelectric method requires high anomaly around faults. Geoseismic method makes interpretation of fault identification very hard and may not be quite right. In GPR method, the depth of the fault should not exceed 50 m (Miyata 1999), while trench and borehole excavation as well as logging methods require a fair knowledge of location and depth of fault. In fact, these methods are complementary for faults identification which may be costly and more often are not able to determinne active faults. Groundwaters level anomaly needs countinuous monitoring of groundwater level variation which may be applied in alluvial plains (Sarvar 2005).

\section{CONCLUSSIONS}

Sinkholes array and their relationship with Lar valley fault implies that fault activities depend upon spatial distribution of sinkholes array, on faults direction.

Four young and five old dolines exist in the study area of Lar valley,they are elongated NW-SE which are superimposed on Lar valley faults direction. Lar valley faults are identificated as F1, F3, FB and F4, F1 is 11 $\mathrm{km}$ long with vertical diplacement about $20 \mathrm{~m}$ with two young sinkholes that formed on its direction that is a good evidence of fault activity, F3 was identificated with $8 \mathrm{~km}$ long and $40 \mathrm{~m}$ vertical displacement. Two young dolines along fault direction were formed after Lar dam refilling which can justify the active fault. FB has $5 \mathrm{~km}$ long with $40 \mathrm{~m}$ vertical displacement. Its mechanism,which is resulted from geological logs corelation implises fault activity. F4 was characterised with $12 \mathrm{~km}$ long and two old sinkholes were formed on its direction. This fault on basis of available data is not active. 


\section{REFERENCES CITED}

Amiri, M., 2003: The Relation Between Ghahavand- Famanin - Kbodarahang Plains Sinkholes with Bedrocks, Proceeding of the third Iranian Engineering Geology and Environment Conference. P213 -226 (Persian)

Allenbach, P., 1966: Geology and Petrography Damavand and Central Alborz, Iran. Mittei Lungen Nr 63 Geologieches Institute. ETH. Zurich

Asadi, M., 1995: About Lar Dam, Technical Report. P 3 , 9, 10, 12 and 20 (Persian).

Clarke, S.M, 2003, Faulting, Fault-Zone Processes \& Hydrocarbon Flow in Three-Dimensional Basin Models. SMC Research. p. 8-11.

Central Geological Survey of Taiwan, 2000, Geological Report of 9.21 Earthquake: Central Geological Survey, Ministry of Economic Affairs, p. 314.

Celik, M. \& N. Onsal, 1999: Grounwater Circulation In the allochthonous Limestone Unite Between Lake Gridev and Kaxanplnarl Spring, Antallya, Southwestern Turkey. V.7. n.5. Springer Hydrogeology journal. p. 483-489

Edgell, H., 1993: Karst and Water Resources in the Hyper arid Area of Northeastern Saudi Arabia. International Symposium on Water Resources in Karsts with Special Emphasis on Arid and Semi Arid zone. Shiraz. Iran. p. 320. (Persian)

Edlance, P.G., 1993: subsurface karst features in Florida, Proceeding of a conference sponsored by the division of sponsored research. University of central Florida. P 199-204

Fazeli, 1988: Karst study and their problems in third Kuhrang tunnel. $2^{\text {nd }}$ International Symposium on karsts water resources I.R.Iran-Tehran-Kermanshah, p. 378. (Persian)

Fernandez, A. \& D. Rudolph., 2001: The Influence of Cenozoic Tectonics on the Groundwater-production Capacity of Fractured Zones: Case study In Sao Paulo, Brazil. v.9. n.2. p. 151-167, and Springer Hydrogeology journal.

Giahi, M., 1989: Exploration study report of about Lar Dams, Lar consulting Engineer: Tehran Water Org. Mistry of Energy. p. 9-11, 19-30. (Persian)

Griffiths, Dh., 1986: Applied Geophysics for Geologists \& Engineers, Translated to Persian

Harp, E.L., Jibson, R.W., Kayen, R.E., Keefer, D.K., Sherrod, B.L., Carver, G.A., Collins, B.D., Moss, R.E.S. \& N. Sitar., 2003: Landslides and liquefaction triggered by the M 7.9 Denali Fault earthquake of 3 November 2002: GSA Today, v. 13, p. 8, 4-10.

Haydari, M., Khanlari, G.H., \& A. Bidokhti., 2003: Study on Carbonates rock solution of Hamadan Power
Generation. Proceeding of the third Iranian Engineering Geology and Environment Conference 189212

Herold, T., Gordan, P., \& F. Zwahlan., 1988: Determining Karsts System Genesis from Tectonics.2ND International Symposium on Karsts Water Resources I.R. Iran-Tehran-Kerman shah -Jolly 1998. p. 590.

Kenz, M., 1988: Pharatic channels formation and underground water direction, $2^{\text {nd }}$ International Symposium on Karsts Water Resources I.R. Iran-TehranKerman shah -Jolly 1998.P.95.

Kusumayudha, B., Ten, M., Notosiswoyo, S. \& R. Sayoga., 2000: Fractal Analysis of River, Cave Systems, and Topography of the Gunungsewu Karsts Area, Central Java, Indonesian. Springer Hydrogeology journal. v.8. n.3, p. 271-278

Maloszewski, P., Herman, A., \& A. Zuber., 1999: Interpretation of Trace Test Performed in Fractured Rock of the Lange Branke Basin, Germany. v.7.n.2. p. 209218 Springer Hydrogeology journal.

Miyata, T., Tanaka, Y., Takada, S. \& B.J. Shih., 2002: GPR survey for the Chi-Chi earthquake rupture in Taiwan. Proc. $2^{\text {nd }}$ Japan-Taiwan workshop on lifeline performance and Disaster Mitigation, 170-175

Milanovic, P., 1981: Karst Hydrogeology. Water Resources Publication, Littletone, Colorado, USA. p. 39-42

Rezai, M., \& A. Zamanian., 1988: the Relationship between Structural System and Karstification in Ardekan Area, Southwest of Iran. p. 550. (Persian)

Saadati, G., \& P. Mohamadi., 2003: Tectonic of Centre Plains of Hamadan Sinkholes, Proceeding of the third Iranian Engineering Geology and Environment Conference. p 286-295 (Persian).

Sarvar, A., 2005: Study on Caspian fault impact on Groundwater Physical and Chemical Properties at Sari to Gorgan ,in North of Iran (Persian).

Shahrabi, M. \& S., Saidi, 1984: Geology and Engineering Geology of Lar dam region. Lar Consulting, Tehran Water Org., Ministry of Energy. p. 12-16, 21-26. (Persian)

Šušteršič, F., 2003: Collapse Dolines, Deflector Fault and Collector Channels. The Virtual scientific Journal

Taylor, R. \& K. Howard., 2000: A Tectonogeomorphic Model of the Hydrogeology of Deeply Weathered Crystalline Rock :Evidence from Uganda. v.8. n.3. p. 279-294 Springer Hydrogeology journal.

Tehran water Org. 1976: Lar Dam and tunnel construction. Ministry of Energy, p. 4. (Persian)

USBR 1978, Burean of Reclamation. First Interagency Working Group, September 1978. 